$\sqrt{3}$

J. Bio-Sci. 24: 67-74, 2016

ISSN 1023-8654

http://www.banglajol.info/index.php/JBS/index

\title{
INCIDENCE OF SPIRALING WHITEFLIES ALEURODICUS DISPERSUS RUSSELL (HEMIPTERA: ALEYRODIDAE) AND ITS NATURAL ENEMIES ON GUAVA ORCHARDS
}

\author{
M Arifunnahar, Z Ferdous, MA Alim and MA Hossain* \\ Hajee Mohammad Danesh Science and Technology University, Dinajpur-5200, Bangladesh
}

\begin{abstract}
Population dynamics of spiraling whitefly and its natural enemies on guava orchards are essential for improvement of existing pest control methods. To find out the seasonal abundance of guava whitefly and its natural enemies and levels of infestations were studied on guava orchards severely infested by A. dispersus. Five guava plants were selected randomly. To determine each stage of the insect density, six leaves comprising upper, middle and lower part of each plant were randomly sampled. Sooty mould infested leaves and presence of natural enemies of $A$. dispersus were also recorded. The highest number of egg mass (5.0) and nymphs (10.0) per leave were found in the month of September. The highest $(0.20 \%)$ ladybird beetle, Scymnus sp. (Coccinellidae: Coleoptera) and Encarsia sp. (0.15\%) were found in the months of October and January, respectively. The number of leaves infested with sooty mould fungus was estimated highest (93\%) during October to January. A. dispersus population was peak in the months of August to January and the associated natural enemies may successfully contribute to the existing pest control methods.
\end{abstract}

Key words: Guava, infestation, natural enemies, spiraling whitefly

\section{Introduction}

The spiraling whitefly, Aleurodicus dispersus Russell (Hemiptera: Aleurodidae) is a destructive invasive pest of many crops including guava throughout the world (Martin 1987, Zhang et al. 2004). It has the potential to become widespread and gradually extended its geographical distribution to South Asia, Australia, Africa, Caribbean Islands, Central America and the Indian Ocean (Zhang et al. 2004). Both immature and adults may cause damage to the host plants. The pest sucks plant juices from the phloem through a slender stylet resulting reduced the growth and vitality of host plants. It also excretes honey dew which covers the surface of the leaves and serves as a medium for the growth of sooty mould (Bryne et al. 1990). The sooty mould may also increase thermal absorption and raise leaf temperature, thus reduces leaf efficiency causing premature death of tissue (Bryne et al. 1990, Gungah 2005). A. dispersus along with A. nubilans (Backton), A. spiniferus (Quaintance) and A. uglami (Ashby) were reported to be the pest of guava in Bangladesh (Scanlan 1995). A loss of $80 \%$ in fruit yield has been recorded in guava attacked by the pest in four continuous months (September to December) in Taiwan (Wen et al. 1995).

Chemical control has widely been used for the management of $A$. dispersus. But all life stages of whiteflies are difficult to control with conventional insecticides because of rapid multiplication, damage under surface of the leaves, thereby not being easily targeted by direct hit of spraying insecticides (Bryne et al. 1990). Spiraling whiteflies were attacked by different natural enemies. Among them the parasitoids Encarsia guadeloupae Viggiani and Encarsia haitiensis Dozier proved to be highly useful in suppressing the spiraling

\footnotetext{
*Author for correspondence: alamgirhstu@gmail.com
} 
whitefly in Pacific Islands, African and Asian countries (Mani and Krishnamoorthy 2002). Successful introduction of natural enemies is one of the suitable biological control methods to save environment also possible in Bangladesh. Thus, ecological data of spiraling whiteflies and its natural enemies are essential for improvement of existing pest control methods and development of new control strategies in integrated pest management of guava orchards in Bangladesh. So far, the information on the population dynamics of spiraling whitefly and associated natural enemies on guava orchards is scanty especially northern part in Bangladesh. Therefore, the present study was aimed to find out the seasonal abundance of guava whitefly and associated its natural enemies in different guava orchards in northern part of Bangladesh.

\section{Materials and Methods}

\section{Experimental site and climatic conditions}

The experiment was conducted at Hajee Mohammad Danesh Science and Technology University (HSTU), Dinajpur from September 2011 to August 2012. The experimental site was located at $25^{\circ} 13^{\prime} \mathrm{N}$ latitude and $88^{\circ} 23^{\prime} \mathrm{E}$ longitudes at elevation of $37 \mathrm{~m}$ above the sea level. Seasonal abundance of $A$. dispersus and associated its natural enemies were studied in three guava gardens at HSTU. The orchards were separated 50 to 100 meters apart.

The experimental area was under subtropical climate characterized by high temperature, high humidity and heavy precipitation with occasional winds in April to September. But scanty rainfall associated with moderate low temperature during October to March. Data on temperature and relative humidity $(\mathrm{RH})$ were recorded by Hobo data logger (H8-003-02, Onset Computer Corporation, Bourne, MA, USA).

\section{Data collection}

Levels of infestations in different months of the year were studied on guava orchards that were severely infested by $A$. dispersus. In each orchard, five guava plants were selected randomly. To determine the number of $A$. dispersus, six leaves comprising two from upper, two from middle and two from lower part of each plant were sampled randomly. From each garden, a total 30 leaves were sampled for and observed insect infestation. The number of egg masses, nymphs, and adults of $A$. dispersus were counting on every sampling day. Sooty mould infested leaves and presence of natural enemies of $A$. dispersus were also recorded. Orchards were free from insecticide applications during the study period.

\section{Statistical analyses}

The mean number of egg masses, nymphs, adults and sooty mould infested leaves and their natural enemies in the orchards were analyzed with analysis of variance (ANOVA) and Tukey-type multiple comparison tests for post-hoc analysis (Zar 2010) using SPSS software (version 16.0).

\section{Results and Discussion}

\section{Seasonal abundance of $A$. dispersus}

The number of egg masses in three guava gardens (Garden A, B and C) recorded in different months is presented in Fig. 1. The results suggested that the highest number of egg masses appeared in the month of November but gradually decreased in different months. Significantly the highest $(F=10.2, d f=2, P<0.001)$ number of egg deposition was found in the orchard $B$. More number of egg masses was produced during the month of September and November which may be considered as the peak period of infestation by $A$. dispersus (Fig. 1). 


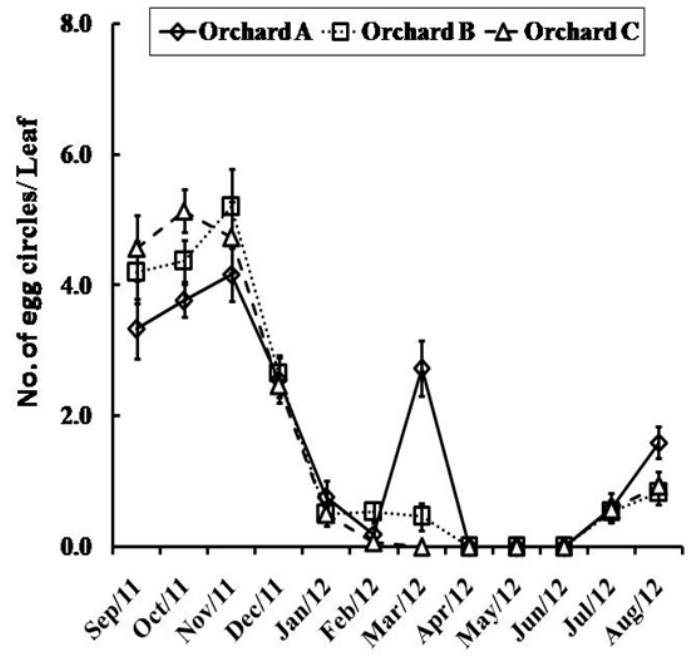

Month

Fig. 1. Seasonal abundance of egg mass of $A$. dispersus on guava leaves in Bangladesh during September 2011 and August 2012.

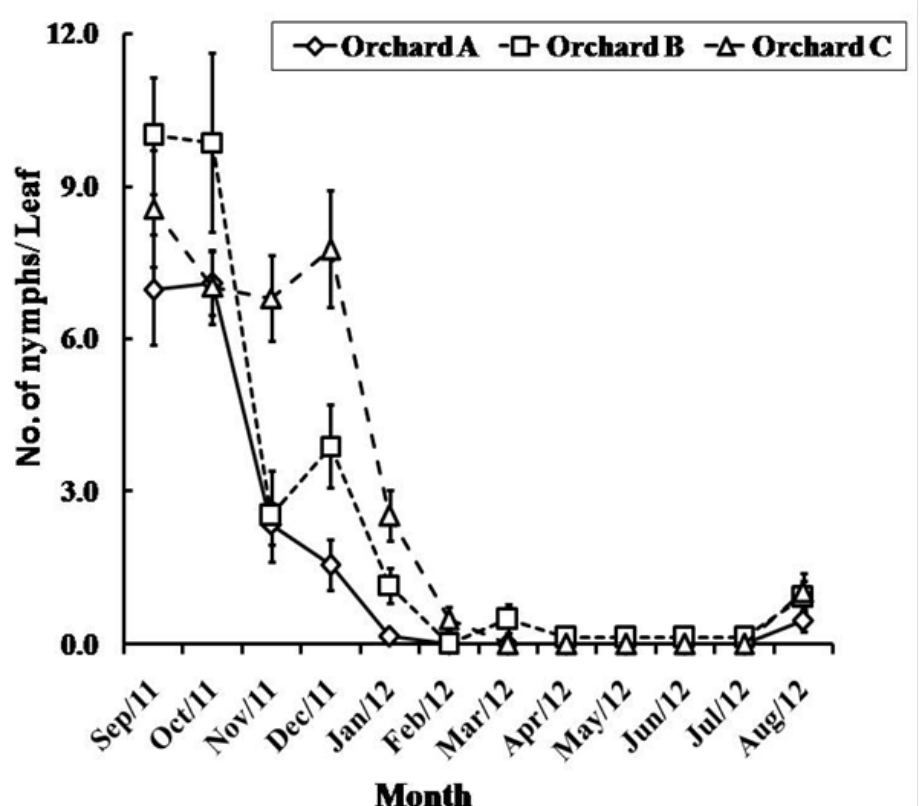

Fig. 2. Seasonal abundance of nymphs of $A$. dispersus on guava leaves in Bangladesh during September 2011 and August 2012. 
The number of nymphs in three guava gardens recorded in the different months was shown in Fig. 2. Maximum number of $A$. dispersus nymphs were found in the orchard $B$. Significantly the highest number of nymphs ( $F=16.5, d f=2, P<0.001$ ) were found in garden $B$ which is different from orchard $A$ and $C$ (Fig. 2). The mean number of nymphs per leaf was significantly the highest in the month of September to October ( $F=$ 86.21, $\mathrm{df}=11, \mathrm{P}<0.001)$ then other month in the year. After January the mean number of nymphs was decreased but no infestation found in the month of February to July.

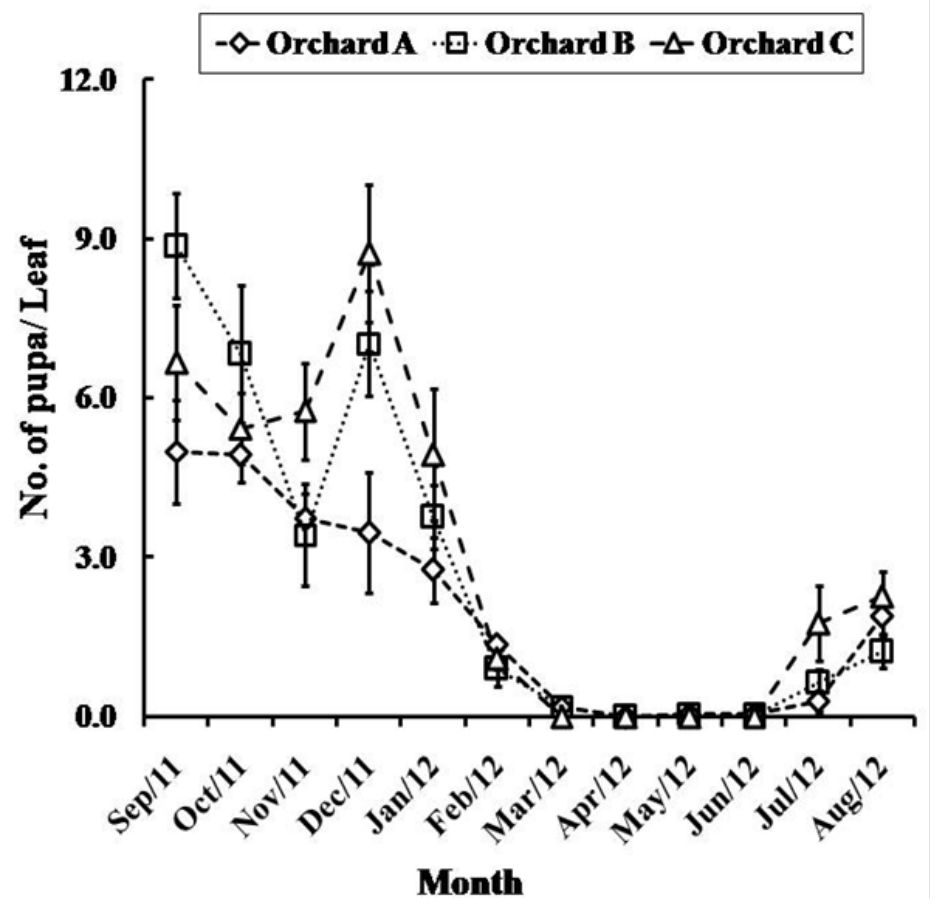

Fig. 3. Seasonal abundance of pupae of $A$. dispersus on guava leaves in Bangladesh during September 2011 and August 2012.

The pupa of spiraling whitefly was highly populated during the month of September (Fig. 3). Increased number of pupae per leaf of guava were found in the orchard $B(F=8.80, d f=2, P<0.001)$ and significantly different from orchard $A$ and $C$. Pupae were found significantly highest in the month of September $(F=51.42$, $d f=11, P<0.001)$ in all three orchards. But no infestation was found in the month of March to June.

The adult of spiraling whitefly was most densely populated in the month of August (Fig. 4). The highest number of adults per leaf on guava plant were found in the orchard $C(F=19.50, d f=2, P<0.001)$ and it was statistically different from orchard $A$ and $B$ (Fig. 4). Adult population were increased in the month of August $(F=18.05, d f=11, P<0.001)$ and continued up to the December but no infestation was found in the month of February to June. 


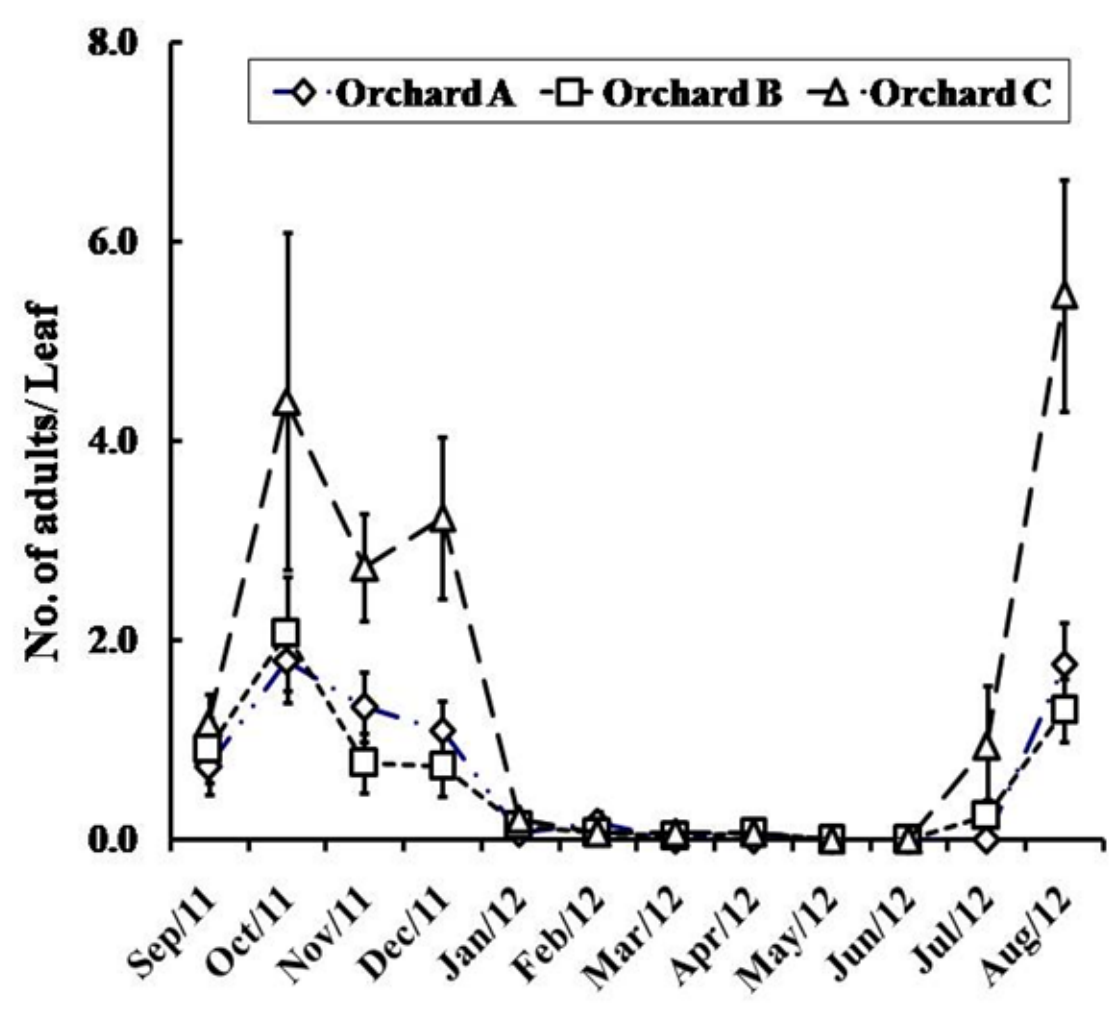

Month

Fig. 4. Seasonal abundance of adults of $A$. dispersus on guava leaves in Bangladesh during September 2011 and August 2012.

Our result suggests that the maximum number of egg masses, nymphs, pupae and adults were found in the month of August to January. But no infestation was found in the month of February to July, probably the reasons that the spiraling whitefly could not survive due to high rainfall. This results also showed that the nymphal population were the highest followed by the pupae and adult. Temperature, rainfall, humidity fog and sunshine may have affect on whitefly population in guava orchards. The present result is matching with those of Horowitz (1986) who reported that a significant drop of whitefly populations at heavy rainy condition. Echelkraut and Cardona (1989) observed that dry conditions are more favorable for Bemisia tabaci than those of high precipitation. Salinas and Sumald (1994) reported the presence of whitefly year-round and showed the negative effect of high temperature and rainfall on the population densities of whitefly. Rashid et al. (2003) also stated the same reason for the decreased number of whitefly populations. The extreme relative humidity, either high or low was unfavorable for the survival of immature stages (Gerling et al. 1986, Gerling 1990). The seasonal distribution of spiraling whitefly highest in the month of August and followed by September to January and then decreased gradually while absent in April in ornamental plants (Alim et al. 2014). 


\section{Seasonal abundance of natural enemies}

Two natural enemies viz. one predatory ladybeetle, Scymnus sp. and pupal parasitoid, Encarsia sp. were found in association with $A$. dispersus during the survey period in three guava orchards (Fig. 5). Results indicated that the highest number of ladybird beetle $(0.20 \%)$ reached in the month of October in orchard $B$. On the other hand, the highest number of Encarsia sp. (0.15\%) in the month of January in orchard B. So far no differences were observed among the recorded three orchards under study.

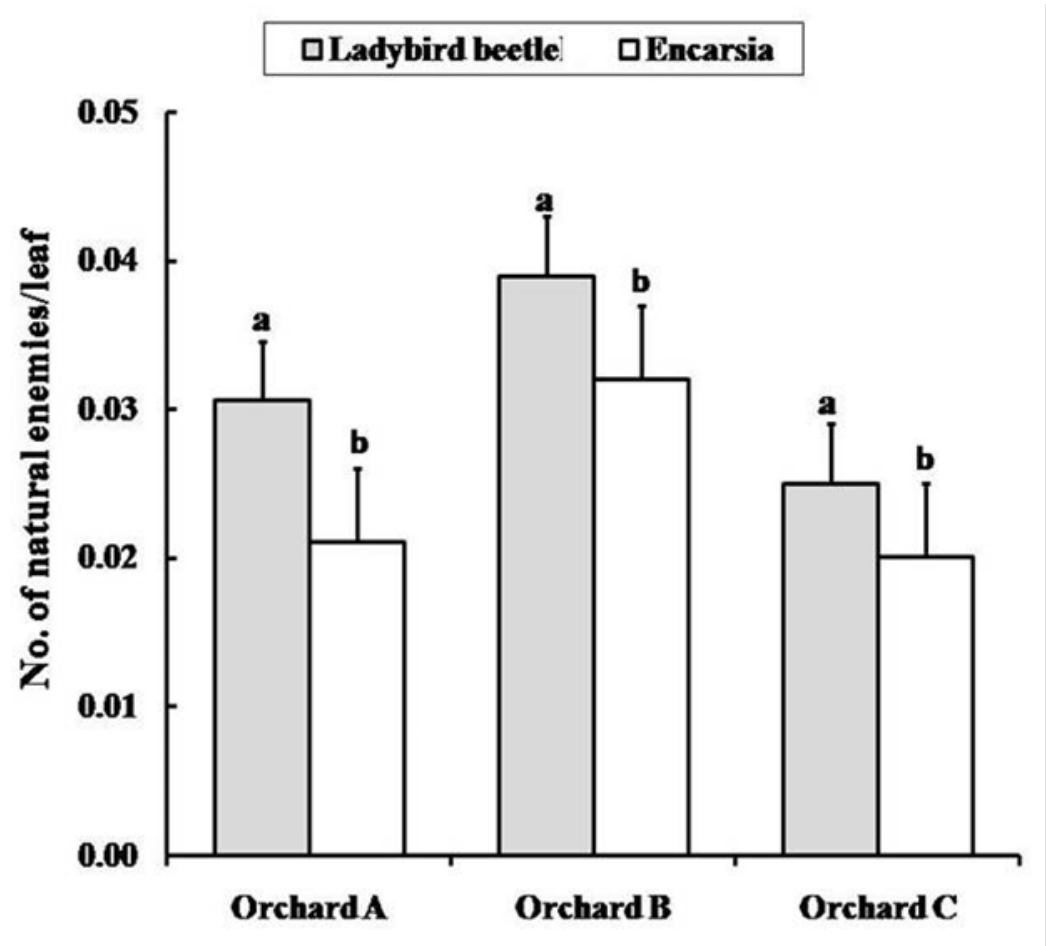

Fig. 5. Seasonal abundance of natural enemies of $A$. dispersus on guava orchards in Bangladesh during September 2011 and August 2012.

Variation in the number of natural enemies was statistically significant in different guava orchards. Mani and Krishnamoorrthy (1999) also found the same species of coccinellid predator and Encarsia sp. on whitefly in India. Rashid et al. (2003) cited that the release of coccinellid predator reduces A. dispersus population density. The population of ladybird beetle, Scymnus sp. and pupal parasitoid, Encarsia sp. were found during the survey period in ornamental plants (Alim et al. 2014). The experimental results showed that the presence of ladybird beetle was affected by the presence of associated ants. The association between ants and the whiteflies was found to be a very common phenomenon in guava orchards. It was also noticed that the presence of ladybird beetles and pupal parasites in the orchard only in the winter months when the whitefly population was comparatively higher. The unavailability of the predator in summer which was hot and humid indicated that the predators might have a temperature or prey density dependent relationship. 


\section{Seasonal abundance of sooty mould infested leaves}

Sooty mould infestation per 30 leaves was highest in the month of October through January in all the studied orchards (Fig. 6). No sooty mould infestation was found from February to July. The month of November showed significantly highest sooty mould infestation $(F=15.27$, df $=11, P<0.001)$.

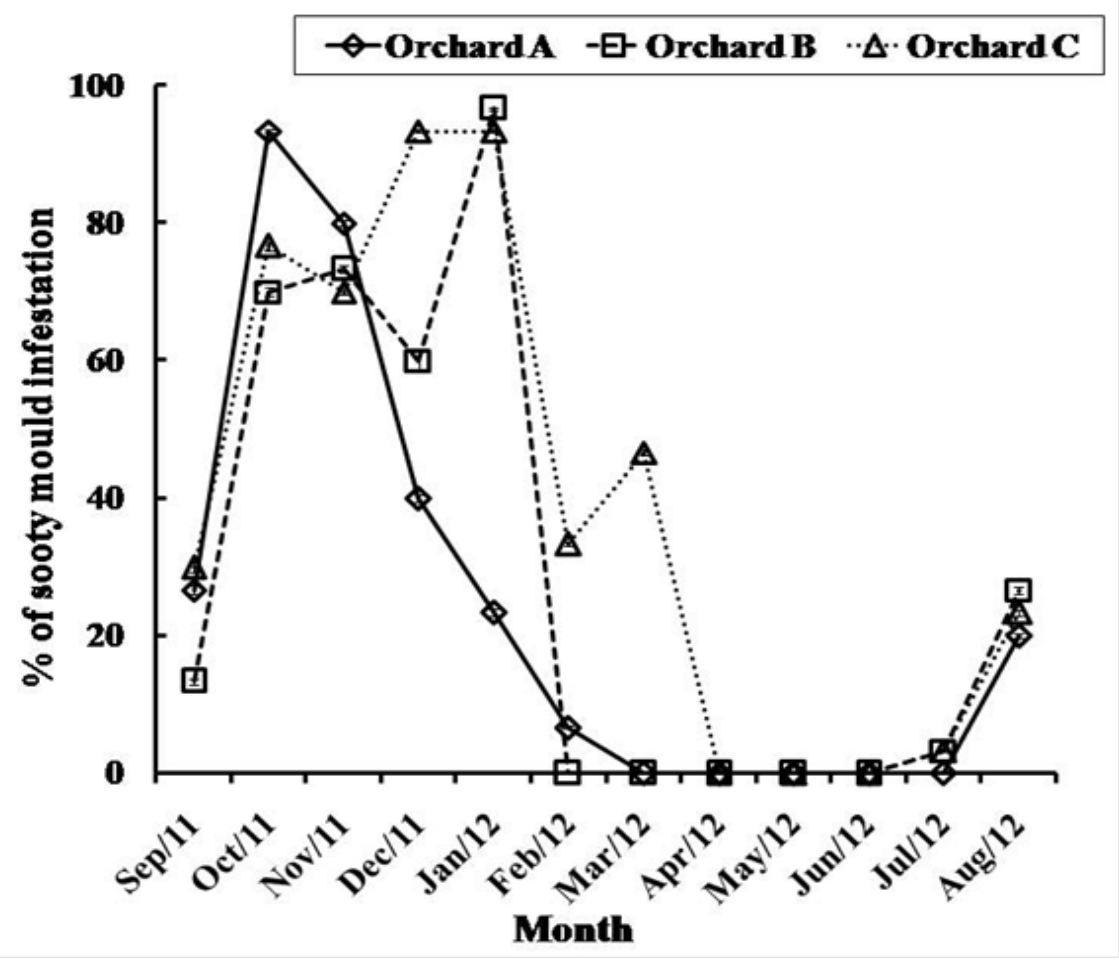

Fig. 6. Sooty mould infestation (\%) on guava leaves in Bangladesh during September 2011 and August 2012.

Abundance of sooty mould infested leaves was statistically significant in different orchards. Our orchards results showed that abundance of sooty mould infested leaves was found only in the winter months when the whitefly population was comparatively higher. But no infestation was found in the months from April to July because of the high temperature, rainfall and humidity. Rashid et al. (2003) also mentioned similar reasons for reduced number of shooty mould infestation in guava orchards. Alim et al. (2014) stated that the highest number of sooty mould infected leaves was found in the month of October in ornamental plants.

\section{Conclusion}

The survey results indicated that the incidence of $A$. dispersus population was peak in the months of August to January while no infestation was found in the months from February to July because of high temperature and high rainfall. Thus the information of seasonal incidence of spiraling whitefly and its associated natural enemies might successfully contribute to the existing pest control methods and the development of new control strategies for guava orchards in Bangladesh. 


\section{Acknowledgement}

The authors acknowledge the Institute of Training and Research (IRT), Hajee Mohammad Danesh Science and Technology University, Bangladesh for financial support.

\section{References}

Alim MA, Hossain MA and Rahman F (2014). Population dynamics of spiraling whitefly on ornamental plants and its natural enemies in Bangladesh. Bangladesh Journal of Entomology 24: 47-55.

Bryne DN, Bellows TS and Parella MP (1990). Whiteflies in agricultural system. In: Gerling D (ed.), Whiteflies: Their Bionomics, Pest Status and Management. Intercept Press, Andover, United Kingdom, 227-226 pp.

Eichelkraut K and Cardona C (1989). Biologia, cria masal y aspectos ecologicos de la mosca blanca Bemisia tabaci (Gennadius) (Homoptera: Aleyrodidae), como plaga del frijol comun. Turrialba 39: 51-55.

Gerling D, Horowitz DAR and Baumgartner J (1986). Auteecology of Bemisia tabaci. Agricultural Ecosystem and Environment 17: 5-19.

Gungah (2005). Biological control of the spiraling whitefly, Aleurodicus dispersus. Food and Agricultural Research Council, Reduit, Mauritius.

Gerling D (1990). Whiteflies: Their Bionomics, pest status and Management. Wimborne, UK. Intercept. 348 pp.

Horowitz AR (1986). Population dynamics of Bemisia tabaci Genn. With special emphasis on cotton field. Agricultural Environment 17: 37-47.

Mani M and Krishnamoorthy A (1999). Natural enemies and host plants of spiraling whitefly Aleurodicus dispersus Russell (Homoptera: Aleyrodidae) in Bangalore. Karnataka Entomology 24: 75-80.

Mani M and Krishnamoorthy A (2002). Classical biological control of spiraling whitefly, Aleurodicus dispersus Russell An appraisal. Insect Science Application 22: 263-273.

Martin JH (1987). An identification guide to common whitefly pest species of the world (Homoptera: Aleyrodidae). Tropical Pest Management 33: 298-322.

Rashid MM, Mofazzel M, Alam MZ, Ibrahim M and Bhuiyan MKA (2003). Seasonal abundance and control of spiraling whitefly, Aleurodicus dispersus Russell on guava. Pakistan Journal of Biological Science 6: 2050-2053.

Salinas MD and Sumalde AC (1994). Life history, seasonal abundance and host range of the wooly whitefly, Aleurothrixus floccossus (Maskell) (Homoptera: Aleyrodidae). Pest management Council of the Philippines, Laguna (Philippines), PMCP. 29 pp.

Scanlan FM (1995). Fruit Production Manuals. Department of Agricultural Extention, Bangladesh Agricultural Department Corporation, Dhaka. 116-117 pp.

Wen HC, Tung CH and Chen CN (1995). Yield loss and control of Spiraling whitefly (Aleurodicus dispersus Russell). Journal of Agricultural Research in China 44: 147-156.

Zar JH (2010). Biostatistical Analysis. $5^{\text {th }}$ edition. Dept. of Biological Science Northern Illinois University.

Zhang W, Mcauslance HJ and Schuster DJ (2004). Repellency of ginger oil to Bemisia argentifolli (Homoptera: Aleyrodidae) on tomato. Journal of Economic Entomology 97: 1310-1318. 